\title{
Kompüter Piratçılı̆̆g ilə Hüquqi Mübarizə Problemləri
}

\author{
Rasim Mahmudov \\ AMEA İnformasiya Texnologiyaları İnstitutu, Bakı, Azərbaycan \\ rasimmahmudov@gmail.com
}

\begin{abstract}
Xülasə- Məqalədə kompüter piratçılığı ilə hüquqi mübarizə problemləri araşdırılır. $O$ cümlədən kompüter piratçıı̆ının mahiyyəti və formaları, onunla mübarizə üsulları şərh olunur. Kompüter proqramlarının hüquqi qorunması formalarının üstünlükləri və çatışmazlıqları analiz edilir.
\end{abstract}

Açar sözlor- kompüter proqramı, kompüter piratçılığı, intellektual mülkiyyət, mü̇llif hüququ, patent hüququ, kommersiya sirri.

\section{GIRISS}

Proqram təminatı sənayesinin inkişafı multiplikativ effekt verərək, informasiya texnologiyaları sənayesinin digər sektorlarının və bütövlükdə, iqtisadiyyatın modernləşdirilməsini və inkişafını, yeni cəlbedici, yüksəködənişli və yüksəktexnoloji iş yerlərinin yaradılmasını stimullaşdırır. Həmçinin dövlətin gəlirlərini və bütün iqtisadi fəaliyyət sahələrində keyfiyyət və effektivliyi artırır.

$\mathrm{Bu}$ gün proqram təminatı sənayesinin inkişafinı əngəlləyən əsas problemlərdən biri kompüter piratçılığıdır. Hazırda bütün dünyada quraşdırılmış hər 3 proqram məhsulundan 1-i pirat proqramdır [1]. Kompüter piratçılığı yalnız proqram məhsullarının istehsalçılarına ziyan vurmur, bütövlükdə, informasiya texnologiyaları sənayesinə ciddi problem yaradır. Nəzərə almaq lazımdır ki, bu gün dünya iqtisadiyyatında və onun milli sektorlarında artım da müəyyən dərəcədə proqram təminatının inkişaf səviyyətindən asılıdır. Kompüter piratçılığının vüsət alması iş yerlərinin itirilməsi, proqramçıların işsiz qalması, əmək haqlarının aşağı olması və ən əsas1, dövlətin gəlirlərinin azalması və informasiya texnologiyalarına investisiya qoymağa marağın azalması deməkdir [2].

Kompüter piratçılığı dövlətin informasiya təhlükəsizliyi baxımından da böyük risk yaradır. Bir çox hallarda pirat distribüter şəbəkəsi vasitəsi ilə konfidensial informasiya, o cümlədən dövlət sirri yayılır.

Kompüter piratçılığı ilə effektli mübarizə aparmaq, proqram təminatı sənayesinin dayanıqlı, effekli inkişafını təmin etmək üçün bir sıra zəruri şərtlərlə yanaşı, müvafiq hüquqi platformanın yardılması vacibdir. $O$ cümlədən proqramlaşdırma fəaliyyətinin yaradıcı fəaliyyət sahəsi olaraq intellektual mülkiyyət obyekti qismində hüquqi qorunması üçün zəruri əsasların yaradılması xüsusi aktuallıq kəsb edir.

\section{KOMPÜTER PİRATÇILIĞININ MAHIYYӨTİ}

"Kompüter piratçılı̆̆ı" termini proqram təminatına dair müəlliflik hüququnun pozulmasını ifadə edir. Birbaşa mənada "müəllif hüququ" anlayışı "nüsxələrini yaratmaq hüququ" kimi izah olunur. Müəllif hüququ, öz növbəsində, intellektual mülkiyyətin qorunması formalarından biri kimi çıxış edir. İntellektual mülkiyyət hüququ dedikdə, fiziki və ya hüquqi şəxslərin intellektual fəaliyyətinin nəticələrinə dair müstəsna hüquq başa düşülür. Müəllif hüququ elmi, ədəbi, incəsənət, kompüter proqramları kimi sahələr üzrə yaradıcılıq nəticələrinə şamil edilir [3].

Proqram məhsulunun lisenziyalı nüsxəsini alarkən istehlakçı yalnız ondan istifadə hüququnu əldə edir. Proqramın özünə müəlliflik hüququ onu yaradanda qalır, alıcının mülkiyyətinə yalnız proqramın yayıldığı maddi daşıyıcılar keçir.

Kompüter piratçılı̆̆ icazəsiz olaraq nüsxələnməsi, istifadəsi və yayılması anlaşılır.

"Müəlliflik hüququ və əlaqəli hüquqlar haqqında" Azərbaycan Respublikasının Qanununa əsasən, pirat proqram təminatının istifadəsi və ya hər hansı formada yayılması müəllif hüquqlarının pozulması hesab olunur [4].

\section{KOMPÜTER PİRATÇILIĞININ FORMALARI}

Kompüter piratçılığının müxtəlif formaları mövcuddur, bunlardan daha çox yayılmış beş formasını fərqləndirmək olar $[2,5]$ :

\section{Son istifadəçi tərəfindən qanunsuz nüsxələmə}

Kompüter piratçılığının daha çox yayılmış növlərindən biri proqram məhsulunun fərdi istifadəçilər və təşkilatçılar tərəfindən qanunsuz olaraq "sadə" şəkildə nüsxələnməsidir. Proqram təminatı sahəsində bu əməl "son istifadəçi tərəfindən nüsxələmə" adlanır. Kompüter piratçılığının bu növünə təşkilatlarda böyük sayda kompüterlərə lisenziyasız proqram məhsullarının quraşdırılması aiddir. Təşkilatdan kənarda bu cür proqram məhsullarının mübadiləsi də həmin kateqoriyaya daxildir.

\section{Proqramlarin kompüterlarin sart disklarina quraşdırılması}

Bir çox hallarda hesablama texnikasının təchizatı ilə məşğul olan şirkətlər proqram təminatının qanunsuz olaraq kompüterlərin sərt disklərinə quraşdırılmasını həyata 
keçirirlər. Yəni proqram təminatının lisenziyasız nüsxələrinin quraşdırıldığı hesablama texnikasının satışını həyata keçirirlər. Proqram təminatının quraşdırılması üçün istər orijinal, istərsə də saxta məhsullardan istifadə olunur.

\section{Saxta nüsxalarin hazırlanması}

Qanunsuz nüsxələmə - genişmiqyaslı saxta məhsulların hazırlanması və onların satış kanalları üzrə yayılmasıdır. Saxta nüsxələrin hazırlanması üçün müasir texnologiyalardan istifadə oluna bilər, bu zaman qablaşdırmanın, loqotiplərin və mühafizə elementlərinin nüsxələnməsi elə yüksək keyfiyyətlə və dəqiqliklə həyata keçirilir ki, saxta mıhsulu orijinal məhsuldan ayırmaq çətin olur. Amma bir sıra ölkələrdə (o cümlədən postsovet məkanında) saxta nüsxələr aşağ keyfiyyətdə istehsal olunur $\mathrm{ki}$, onları da orijinallarından fərqləndirmək çox asandır.

\section{Lisenziya məhdudiyyatlarini pozma}

Lisenziya tələblərinin pozulması o halda baş verir ki, proqram təminatının xüsusi qiymət güzəştləri və xüsusi şərtlərlə satışı müvafiq tələblərə cavab verməyənlər tərəfindən satılır. Buna misal kimi akademik lisenziyaların kommersiya müəssisəsinə satışını göstərmək olar.

\section{Internet piratçılı $\breve{g} l$}

İnternet piratçılığı - proqram məhsullarının qanunsuz nüsxələrinin İnternet vasitəsi ilə yayılmasıdır. Piratçılığın bu növü ona görə xüsusi olaraq fərqləndirilir ki, hazırda proqram təminatının qanunsuz nüsxələnməsi və yayılmasında İnternet böyük rol oynayır. İnternet meydana gəldikdən sonra piratçılıq daha geniş miqyas almağa başlaylb. Pirat proqram məhsullarının reklam edilməsində də İnternetin imkanlarından geniş istifadə olunur.

\section{PİRATÇILIQLA MÜBARİZ ÜSULLARI}

Dünya təcrübəsinə əsaslanaraq, piratçiliqla mübarizədə dörd əsas istiqaməti fərqləndirmək olar [6, 7]. Bunlardan birincisi təbliğat-təşviqatdır ki, bu zaman lisenziyalı məhsulun üstünlükləri nümayiş olunur və pirat nüsxələrin çatışmazlıqları izah olunur. $\mathrm{Bu}$ işdə KIVV və PR şirkətləri böyük rol oynaya bilərlər.

İkinci istiqamət kimi istifadəçilərə təlim keçmək, onları öyrətmək nəzərdə tutulur. Belə ki, tematik seminarların, konfransların keçirilməsi, metodik və sorğu xarakterli ədəbiyyatın nəşri vasitəsi ilə istifadəçilərə qanuni əsaslarla daha ucuz proqram təminatını əldə etməyin yolları öyrədilir.

Üçüncü istiqamət kimi qiymət siyasətini göstərmək olar. Proqram məhsulunu qanuni yolla əldə etmək üçün məsrəflər nə qədər çox olarsa, onun qeyri-qanuni yolla daha ucuz qiymətə əldə edilməsi halları bir o qədər artır. Kasıb ölkələrdə piratçılığın səviyyəsinin daha yüksək olması da bunun əyani göstəricisidir. Ona görə də proqram təminatı istehsalçıları kasıb ölkələrə münasibətdə güzəştli qiymət siyasəti həyata keçirməlidirlər ki, piratçılıq halları minimuma ensin.

Dördüncü istiqamət kimi hüquqi metod və ya "güc metodu" tətbiq edilir. $\mathrm{Bu}$ metod qeyri-leqal məhsulların istehsalçıları və satıcılarının müəyyən edilərək, onların cinayət və ya inzibati məsuliyyətə cəlb edilməsini nəzərdə tutur. $\mathrm{Bu}$ prosedur dövlətin hüquq-mühafizə orqanlarının - polis, prokurorluq, antiinhisar, gömrük və məhkəmə orqanlarının birgə fəaliyyəti sayəsində effektli ola bilər. "Oqli mülkiyyət hüquqlarının təminatı və piratçılığa qarşı mübarizə haqqında" Azərbaycan Respublikasının Qanunu da pirat intellektual mülkiyyət nümunələrinin, o cümlədən kompüter proqramlarının yaradılması və yayılması ilə hüquqi metodlarla mübarizə aparılması sahəsində münasibətləri tənzimləyir [8].

\section{KOMPÜTER PROQRAMLARI MÜLKIYYЭT HÜQUQUNUN OBYEKTİ KİMİ}

Dünyada kompüter proqramı ilk dəfə 1961-cı ildə ABŞ-da hüquqi qorunmanın obyekti kimi qeydiyyata alınmışdır. Kompüter piratçılığı hüquq pozuntusu kimi ilk dəfə 1980-ci ildə ABŞ-da Microsoft şirkətinin qurucularından olan Bill Qeytsin böyük səyi nəticəsində tanınmışdır. Həmin il ABŞ Konqresi kompüter proqramını intellektual mülkiyyət hüququnun obyekti kimi müəyyən etmişdir. Beləliklə, o vaxtdan etibarən kompüter piratçılı̆̆ rəsmi olaraq oğurluq kimi dəyərləndirilməyə başlanmışdır. Tədricən digər qabaqcıl ölkələr də ABŞ-ın bu təcrübəsindən istifadə edərək analoji addımlar atmağa başlamışlar [8].

Qeyd etmək lazımdır ki, hüquqi qorunma heç də bütün kompüter proqramlarına şamil edilmir. Müxtəlif dildə və formada ifadə edilən, giriş mətninə və obyekt koduna malik olan kompüter proqramları hamı üçün əlyetərlidir. Kompüter proqramları hüquqi qorunmaya ədəbi əsər kimi cəlb edilir. Həmçinin kompüter proqramı müəllifin (həmmüəlliflərin) yaradıcılıq fəaliyyətinin nəticəsini özündə əks etdirməlidir.

Azərbacan qanunvericiliyinə görə, kompüter proqramı maşınla oxunan formada ifadə edilən və müəyyən məqsədə və ya nəticəyə nail olmaq üçün kompyuteri hərəkətə gətirən sözlər, kodlar, sxemlər və başqa şəkildə təlimatların məcmusudur. Kompüter proqramına, həmçinin onun hazırlanması gedişində əldə edilən hazırlıq materialları və onun doğurduğu audiovizual təsvirlər də daxildir [4].

Azərbaycan qanunvericiliyində kompüter proqramlarının qorunması ilkin mətn və obyekt kodu da daxil olmaqla, istənilən dildə və formada ifadə edilən proqramların bütün növlərinə, o cümlədən əməliyyat sistemlərinə şamil edilir.

Lakin heç də bütün ölkələrdə kompüter proqramlarının əsasında dayanan ideya və prinsiplərə, interfeysin və alqoritmin təşkilinin ideya və prinsiplərinə, eləcə də, proqramlaşdırma dillərinə hüquqi qorunma şamil edilmir. Həmin ölkələrə misal kimi ABŞ və Yaponiyanı göstərmək olar [8].

\section{KOMPÜTER PROQRAMLARININ HÜQUQİ QORUNMASININ FORMALARI}

Kompüter piratçılığı ilə effektli mübarizə aparmaq üçün kompüter proqramlarının hüquqi qorunmasının təmin edilməsi vacibdir. Hazırda beynəlxalq praktikada kompüter 
proqramlarının hüquqi qorunmasının üç mümkün forması tətbiq edilir [3, 9]:

1. müəllif hüququnun obyekti kimi;

2. patent hüququnun obyekti kimi;

3. kommersiya sirri hüququnun obyekti kimi.

Kompüter proqramlarının hansı hüquqi vasitələrlə qorunması məsələsi ilə bağlı elmi diskussiyalar artıq onillərdir ki, davam edir. Bir tərəfdən, proqram istehsal məhsuludur, onun dəyəri formasında deyil, məzmununda ifadə olunur. Proqramda vacib olan ona daxil edilmiş alqoritmlər və texniki həllərdir. Lakin kompüter proqramlarına patent müdafiəsinin tətbiqi bir sıra problemlər yaradır. Patentin yüksək qiyməti, uzun ekspertiza proseduru ona gətirib çıxarır ki, proqram təminatının böyük bir hissəsi müdafiəsiz qalır. Obyektlərin patentləşdirilməsi isə proqram təminatı bazarının daha da inhisarlaşmasına gətirib çıxarır.

Digər tərəfdən, kompüter proqramları digər müəllif hüququ obyektləri ilə bir sıra ümumi xüsusiyyətlərə malikdir. Müəllif hüququ işıq üzü görən və görməyən, maddi daşıyıcısından, təyinatından və dəyərindən asılı olmayaraq obyektiv formada təqdim edilən istənilən kompüter proqramına şamil edilir. Müəllif hüququ həmin obyektlərin yaradılması ilə qüvvəyə minir. Kompüter proqramlarına dair müəlliflik hüququnun tanınması üçün qeydiyyat və digər formal prosedurlar tələb olunmur [8].

Lakin kompüter proqramlarının müəllif hüquqlarının obyekti kimi qorunması da bir sıra problemlər yaradır. Osas problem ondan ibarətdir ki, müəllif hüquqularının əsasında obyektin unikallığı, sərbəst şəkildə identik ədəbiyyat, incəsənət əsərinin yaradılmasının qeyri-mümkünlüyü prinsipi dayanır. Məhz buna görə də əsərə müəllif hüququnun tanınması üçün xüsusi qeydiyyat tələb edilmir. Kompüter proqramlarının unikallıq xüsusiyyətinə malik olmaması onu müəllif hüquqları sferasına daxil edilməsində problemlər yaradir.

Ümumiyyətlə, kompüter proqramlarının patenlə müdafiəsinin müəllif hüquqları ilə qorunması ilə müqayisədə üstünlükləri vardır. Belə ki, müəllif hüququ əsərin obyektiv formasını, patent hüququ isə əsərin əsasında dayanan əsas prinsiplori qoruyur.

Kompüter proqramlarının kommersiya sirri hüququ vasitəsilə qorunmasının da öz xüsusiyyətləri mövcuddur. $\mathrm{Bu}$, ilk növbədə, kompüter proqramının giriş kodunun, həmçinin proqramın qanuni şəkildə əldə edilməsinin autentifikasiyası üçün nəzərdə tutulan verilənlərin müdafiəsinə aiddir. Giriş kodunun dəyəri, məlum olduğu kimi, obyekt kodunun dəyərinə olan hüquqdan dəfələrlə yüksəkdir. Belə ki, giriş kodu proqramin strukturu, iş prinsipləri, ona daxil edilən alqoritmlər haqqında informasiya daşıyır ki, bütün bunlar da kommersiya dəyərinə malikdir. Rəqiblər giriş kodunu ələ keçirərək, analoji proqramların işlənməsi üçün xərcləri əhəmiyyətli dərəcədə azalda və həmin qənaət olunmuş vəsaiti proqramların təkmilləşdirilməsinə yönəldə, bununla da, bazarda üstünlük qazana bilərlər [3].

Proqramın potensial alıcısı giriş kodunu əldə edərkən, ola bilər ki, hazır proqramı əldə etməsin. O, giriş kodundan istifadə edərək, lazımi modifikasiya etməklə proqramı öz ehtiyaclarına uyğun hazırlaya bilər. Proqramı qanuni şəkildə əldə edənlərin autentifiksiyası üçün nəzərdə tutulan informasiya da kommersiya sirrinin əlamətlərinə malikdir. Bu informasiya proqramın qanuni nüsxəsində verilən parolu, seriya nömrəsini, yaxud xüsusi faylı özündə əks etdirir. Həmin informasiya olmadan müvafiq proqramdan istifadə etmək mümkün deyil.

Qeyd edilən informasiya üçüncü şəxsə məlum olarsa, o, müvafiq proqramı satın almadan ondan istifadə edə bilər. $\mathrm{Bu}$ cür informasiya, xüsusən, sərbəst yayılan proqramlar üçün daha qiymətlidir. Parolu bilən, yaxud xüsusi açar faylına malik olan istənilən şəxs bu cür proqramlardan onu hazırlayana heç bir haqq ödəmədən istifadə edə bilər. Müvafiq hüquq sahibinə bu cür informasiyanın İnternet vasitəsilə yayılması daha böyük ziyan verir [8].

Beləliklə, qeyd etmək olar ki, kompüter proqramlarının hüquqi qorunması ilə bağlı əsas problem də məhz onların intellektual mülkiyyət kateqoriyası daxilində necə təsnifləşdirilməsi ilə bağlıdır. Yəni burada mübahisəli məqam ondan ibarətdir ki, kompüter proqramları intellektual mülkiyyət kimi müəllif hüquqlarının, patent hüquqlarının, yoxsa kommersiya sirri hüquqlarının obyekti kimi qorunmalıdir?

Bütün inkişaf etmiş ölkələr, həmçinin Avropa Birliyi müəllif hüququnu seçiblər. Azərbaycan qanunvericiliyində də kompüter proqramları müəllif hüquqlarının obyekti kimi qorunması nəzərdə tutulur.

Bununla belə, son vaxtlar ABŞ və Yaponiyada əks tendensiyalar müşahidə olunur. Belə ki, həmin ölkələrdə kompüter proqramlarının patent kimi qeydiyyatdan keçirilməsi faktları artmaqdadır. Artıq ABŞ-da proqram təminatı məhsullarının və işgüzar metodların əksəriyyətinin patent hüququ ilə qorunmasına başlanılmışdır. Yaponiyada da artıq proqram təminatı və işgüzar metodlar onların abstrakt ideyalar kimi yox, texniki ideyalar kimi qiymotləndirildiyi halda patentləşdirilir. Avropa Patent Konvensiyasına və Avropa Patent Təşkilatının üzvü olan bir sıra ölkələrin qanunvericiliklərinə uyğun olaraq, kompüter proqramları və işgüzar metodlar hələlik patent müdafiəsi sferasına daxil edilməmişdir. Lakin son illər praktikada uzun və intensiv disskussiyalar nəticəsində bu məsələyə münasibət dəyişməkdədir [3].

\section{NӘTICə}

Kompüter proqramları intellektual mülkiyyət hüququnun obyekti kimi spesifik texnoloji xüsusiyyətlərə malikdir. Ona görə də ənənəvi intellektual mülkiyyət hüququnun metod və prinsiplərini tətbiq etməklə kompüter proqramlarının effektli hüquqi müdafiəsini təmin etmək mümkün deyil. Kompüter proqramları, eyni zamanda, müəllif hüququnun, patent hüququnun və kommersiya sirri hüququnun obyekti kimi 
unikal xüsusiyyətlərə malikdir. Mövcud dünya təcrübəsi göstərir ki, qanunvericilər kompüter proqramlarını hüquqi qorunmaya cəlb edərkən intellektual mülkiyyətin qeyd edilən formaları arasında seçim etmək məcburiyyətində qalırlar. Amma bu hüquqi qorunma formalarının hər birinin üstünlükləri ilə yanaşı, öz çatışmazlıqları da mövcuddur. Kompüter piratçılığının geniş yayılmasında da həmin çatışmazlıqlar mühüm rol oynayır. Buna görə də kompüter proqramlarının spesifik texnoloji xüsusiyyətləri qeyd olunan hüquqi qorunma formalarının üstünlüklərini özündə birləşdirən, eyni zamanda, çatıçmazlıqlarını aradan qaldırmağa qadir olan intellektual mülkiyyət hüququnun yeni altsahəsinin sahəsinin formalaşdırılmasını diktə edir.

\section{ӘDӘBIYYAT}

[1] BSA Global Software Survey 2016, http://www.bsa.org

[2] Л.Н. Чевтаева, Интернет-пиратство: вчера и сегодня, Вестник СГТУ. 2013. № 4 (73), c. 284-289.

[3] D.E.Bouchoux, Intellectual Property: The Law of Trademarks, Copyrights, Patents, and Trade Secrets, Cengage Learning, 2016, 576 p.

[4] "Müəllif hüququ və əlaqəli hüquqlar haqqında" Azərbaycan Respublikasının Qanunu, http://www.wipo.int/edocs/lexdocs/laws/az/az/az003az.pd

[5] S.Meyer, Understanding Digital Piracy, The Rosen Publishing Group, 2013, $48 \mathrm{p}$.

[6] N.Jansma, Effective Anti-Piracy Methods to employ in Software Development, Research Paper, EECS481 Software Engineering, The University of Michigan, 6 p., https://www.researchgate.net

[7] И.А.Цветков, "Пиратство и усиление борьбы с ним в сети интернет”, Вестник Омского университета. Серия "Право”, 2015, № 1 (42), c. 164-174.

[8] "Әqli mülkiyyət hüquqlarının təminatı və piratçılığa qarşı mübarizə haqqinda" Azərbaycan Respublikasının Qanunu, http://www.president.az/articles/536

[9] R.M.Đliquliyev, R.Ş.Mahmudov, İnternet mühitində intellektual mülkiyyət hüquqlarının qorunması məsələləri. Ekspress-informasiya. İnformasiya cəmiyyəti seriyası, Bakı, "İnformasiya Texnologiyaları" nəşriyyatı, 2010

[10] R.M.Đliquliyev, R.Ş.Mahmudov, "İnformasiya cəmiyyətində intellektual mülkiyyət hüquqlarının qorunması problemləri”, İnformasiya cəmiyyəti problemləri, 2015, №2, s.4-14, 